\title{
Factors Affecting Food Purchases in Vysočina Region with Focus on Regional Food
}

\author{
Martina Chalupová ${ }^{1}$, Stanislav Rojík ${ }^{3}$, Ladislav Pilař $\breve{r}^{3}$, Martin Prokop ${ }^{2}$ \\ ${ }^{1}$ Department of Economics, College of Polytechnics Jihlava, Czech Republic \\ ${ }^{2}$ Department of Mathematics, College of Polytechnics Jihlava, Czech Republic \\ ${ }^{3}$ Detartment of Management, Faculty of Economics and Management, Czech University of Life Sciences \\ Prague, Czech Republic
}

\begin{abstract}
The article presents the results of a research study that analyses chosen factors that affect food purchases in Vysočina Region with focus on a regional food. The quantitative research, conducted in 2015 in each district of Vysočina Region (Jihlava, Žd’ár nad Sázavou, Třebíč, Havlíčkův Brod and Pelhřimov), analysed the opinions of 819 respondents. They were selected by quota sampling methods according to gender. Data have been processed with correspondence analysis; the results show that brand and price are significant factors that influence consumers in Vysočina Region when they buy food, the labels on the food packaging do not seem to be a strong signal of quality. Statistical tests based on contingency tables proved that regional food is strongly preferred by women and consumers over 65 years old.
\end{abstract}

\section{Keywords}

Regional food, consumer buying behaviour, food industry, marketing, branding.

Chalupová, M., Rojík, S., Pilař, L. and Prokop, M. (2019) "Factors Affecting Food Purchases in Vysočina Region with Focus on Regional Food", AGRIS on-line Papers in Economics and Informatics, Vol. 11, No. 3, pp. 35-44. ISSN 1804-1930. DOI 10.7160/aol.2019.110304.

\section{Introduction}

Food and place are intertwined in robust ways, the place of food seems to be center of the discourses in the emerging movements and practices, that represent resistance and counter-pressure to conventional globalizing food system (Van Der Ploeg, 2008). Demand for regional food has been increasing in the Czech Republic in the last decade (Turčínková, Kalábová, 2011; Bošková, Ratinger, Kličková, 2016), the similar trend emerged in EU countries from the beginning of this century (e.g. Loureiro, Umberger, 2005; McEntee, 2010; Reiff et al., 2016; Fogarassy et al., 2018). A regional product is the one, whose quality and (or) fame can be attributed to its region of origin define and it is marketed using the name of the region of origin (Van Ittersum, Candel and Meulenberg, 2007; Śmigielska and Stefańska, 2017). Fonte (2010) does not only associate it with qualitative and geographical characteristics (i.e. direct connection with the region / particular territory), but also with its inhabitants, institutions, and she also notes the importance of the historical context (tradition). Lošt’ák, Karanikolas, Draganová and Zagata (2014) speak in this context rather about the retro-innovations, i.e. the application of the current form of traditional methods. Čadilová (2011) adds that regional products must above all meet the basic requirement that they should be made from local raw materials and also be somewhat exceptional. Frequently, manual work and environmental friendliness are required for such products (de Bruin, 2011). Hájková (2014), who explored the potential of using VYSOČINA Regional Product label in tourism, emphasizes the aspect of the authenticity of such products - creating a specific experience for the visitors. Petrenko, Brinkman and Olsson (2014) emphasize among other characteristics of regional food the importance of distinct regional identity - such products should be a ,regional specialty', that can be consumed locally but also being marketed on the national or international level. The authors distinguish regional and local food, admitting the concept is open to different interpretations (see Table 1).

Regional foods are distinguished from local foods, which should primarily have a short distribution 


\begin{tabular}{|l|c|c|}
\hline Attributes & Local Food & Regional Food \\
\hline Geography - food produced and processed within a local area $(100-200 \mathrm{~km})$ & $\mathbf{X}$ & $\mathbf{X}$ \\
\hline Geography - consumed within a local area $(100-200 \mathrm{~km})$ & $\mathbf{X}$ & - \\
\hline Distribution - short supply chain (i.e. with few intermediaries) & $\mathbf{X}$ & - \\
\hline Production - produced in an environmentally sustainable and socially responsible manner & $\mathbf{X}$ & $\mathbf{X}$ \\
\hline Identity - distinct regional identity (e.g. label) & - & $\mathbf{X}$ \\
\hline
\end{tabular}

Source: Petrenko, Brinkman, Olson (2014, p.12), own adjustment

Table 1: Attributes of regional and local food (X marks the relevance of the attribute).

chain with a low number of intermediaries from the producer to the consumer - from the use of local ingredients and ingredients that have been grown / farmed, processed and consumed entirely within a given geographically defined area an action radio in the range of 100 to $200 \mathrm{~km}$. De Lind (2011) sees the value of local foods in two main areas: it is a tool for local development (or a restart of development) as well as a personal development tool (in terms of positive health effects, when these products are perceived as more fresh and ripe). Blake et al. (2010) believe that the essence of local food is hidden in associations that are connected with the word, local ${ }^{6}$ : trust, shared values, quality, heritage, simplicity, craftsmanship, and the community. This ,international' consumer behaviour also confirms f. e. Maitah et al. (2015). Born and Purcell (2006) have voiced doubts and warned against ,local traps ' - the local scale may not automatically pose positive product characteristics. Conversely, if the product remains local for a long time, the possible explanation is that no one else is interested in it.

As it is also evident from Tab. 1, regional foods, in contrast to local ones, have a particularly strong regional identity, possibly via regional labelling. However, distinguishing local and regional foods can be viewed as redundant to the Czech market, especially for consumers. On the other hand, it is very important to avoid misuse of the concept of a regional product, f.e. when common conventional products produced by multinational corporations are beeing labelled and marketed as ,regional products'. In the United States, an attention is drawn to the fact that, as a result of globalization pressures, there is an increasing occurrence of the fact that a food product bears the name of a place, but that does not mean that it really comes from this place (Giovannucci et al., 2010). Others (Ilbery, Maye, 2007; Healy, McDonaugh, 2009) also note that regional foods are partly made from ingredients that do not come from the region and sometimes also without the use of local labour. Wilson and Whitehead (2012), based on their research (as well as Sonnino and Marsden, 2005, and Schermer, 2015), talk about the dichotomy between regional and conventional foods, where, due to the same ingredients used, there is no real distinction between the two concepts. Healy and Mc Donagh (2009) then warn that ,wrongful ${ }^{\circ}$ use of regional or local terms can have detrimental consequences for the regions themselves as it can wash away the last remnants of ,true regional/local ${ }^{\text {c }}$ identity associated with a particular territory.

Czech experts, who identified the visions of the food industry in the Central European region (FutureFood6 project) by 2020, indicated as the basic vision increased the availability of quality regional/ local specific foods. The most crucial starting point is the definition of regional (local) food, that should be discussed. Furthermore, there is a pressing need of the criteria determination by which these foods could be identified as regional/ local specifics, in cooperation with state institutions and associations of entrepreneurial subjects in agriculture and food industry (Valenta, Hladík et al., 2011; Musová et al., 2018).

The paper first discusess respondents ' food buying process with a special focus on regional food, the next section is devoted to the methodology of the research, followed by a discussion of the results. Research limitations and recommendations for the future analysis focus are presented at the end of the article.

\section{Materials and methods}

The research was focused on the level of awareness of the food labels in Vysočina Region with special focus on the regional labels: VYSOČINA Regional Product ${ }^{\circledR}$ and Regional Food Vysočina Region and consumers" behaviour when buying food. The research was conducted in January - March 2015 in each of the region's district; it had a quantitative design. The structure was determined in accordance with the structure of Vysočina Region population, data came from the Czech Statistical Office (2015), see Table 2. 


\begin{tabular}{|l|l|c|c|}
\hline \multirow{3}{*}{ Criterion } & \multicolumn{1}{|c|}{ Group } & Respondents & Respondents \\
\cline { 3 - 4 } & & Abs. fr. & Rel. fr. \\
\hline \multirow{3}{*}{ Total } & Population aged 15-65 & 819 & 100.00 \\
\hline \multirow{5}{*}{ Agender } & Male & 418 & $51 \%$ \\
\cline { 2 - 4 } & Female & 401 & $49 \%$ \\
\hline \multirow{5}{*}{ District } & $15-25$ years & 192 & $23 \%$ \\
\cline { 2 - 4 } & $26-35$ years & 153 & $19 \%$ \\
\cline { 2 - 4 } & $36-45$ years & 171 & $21 \%$ \\
\cline { 2 - 4 } & $46-55$ years & 124 & $15 \%$ \\
\cline { 2 - 4 } & $56-65$ years & 122 & $15 \%$ \\
\cline { 2 - 4 } & 65+ years & 57 & $7 \%$ \\
\hline & Jihlava & 230 & $28 \%$ \\
\cline { 2 - 4 } & Havlíčkův Brod & 93 & $11 \%$ \\
\cline { 2 - 4 } & Pelhřimov & 124 & $15 \%$ \\
\cline { 2 - 4 } & Třebíč & 184 & $23 \%$ \\
\cline { 2 - 4 } & Žd'ár nad Sázavou & 188 & $23 \%$ \\
\hline
\end{tabular}

Source: own research

Table 2: Vysočina Region population aged 15-65+ by gender, age groups and districts.

Questionnaires (857) were completed using the help of interviewers outside supermarkets/hypermarkets, and shopping centres, 819 of them were processed (quota sampling according to gender) in all districts of Vysočina Region - Jihlava, Havlíčkův Brod, Pelhřimov, Třebíč and Žd'ár nad Sázavou (not the quota sampling). The fact, that data was collected in front of larger retail chains, impacted the results, as this type of shops is usually not listing regional products as much as small/local shops located in the countryside (f.e. COOP). Respondents were asked to complete demographic questions and the ones regarding their buying decisions process (what factors influence their buying decisions). They were also asked to answer what food labels do they recognise and if they are aware of particular regional labels.

Data have been processed with correspondence analysis (CA), a multivariate statistical technique that provides a means of displaying or summarising a set of data in two-dimensional graphical form (Nenadić, Greenacre; 2007). Contingency tables display relations among categorical data, depending on the character of the data we then use suitable tests of independence. For the case of a contingency table of the $r \times c$ type ( $r$ is the number of rows, $c$ is the number of columns) the test statistic is the most often used (Řezanková, 1997):

$\chi^{2}=\sum_{i} \sum_{j} \frac{\left(n_{i j}-e_{i j}\right)^{2}}{e_{i j}}$,

$e_{i j}$ is an expected and $n_{i j}$ observed frequency. The statistic $\chi^{2}$ in Pearson's chi-square test with asymptotical distribution is beeing used, the null hypothesis of the test assumes independence, for further details see Hebák et al. (2010). To use the Pearson's chi-square test the condition that a maximum $20 \%$ of the expected frequencies are less than five must be met, see Hendl (2012). In another case, we use Fisher's exact test, or we calculate simulated $\mathrm{p}$-value of $\chi^{2}$ statistic.

Correspondence analysis (CA) is an exploratory technique that provides a mean of displaying or summarising a set of data in two-dimensional graphical form (Šánová, Svobodová, Laputková, 2017). It is traditionally applied to contingency tables - CA decomposes the chi-squared statistic associated with this table into orthogonal factors. The distance among single points is defined as a chi-squared distance. The distance between i-th and i'-th row is given by the formula:

$$
D\left(i, i^{\prime}\right)=\sqrt{\sum_{j=1}^{c} \frac{\left(r_{i j}-r_{i^{\prime} j}\right)^{2}}{c_{j}}},
$$

where $r_{i j}$ are the elements of row profiles matrix $R$ and weights $c_{j}$ are corresponding to the elements of column loadings vector $c_{T}$, which is equal to mean column profile (centroid) of column profiles in multidimensional space. The distance between columns $j$ and $j$ ' is defined similarly. The aim of this analysis is to reduce the multidimensional space of row and column profiles and to save maximally original data information, within the ambit of explorative-descriptive analyses. The total variance of the data matrix is measured 
by the inertia, which resembles a chi-square statistic but is calculated on relative observed and expected frequencies (Di Franco, 2015). There have also been contingency tables constructed based on respondents' age and gender; Chi-square test was counted to confirm or disapprove relation between variables. Software UNISTAT and STATISTICA were used for processing primary data.

\section{Results and discussion}

The first part of the research focused on the respondents' buying behaviour. An opening question aimed to find out, whether the respondents were affecting not only their own food choices but also the other members of their household. Most people (507 of 819 , i.e. $61.9 \%$ ) bought the food not only for themselves but also for the whole family. Others $(185 ; 22.6 \%)$ bought it mostly for themselves, and only a minor part $(127 ; 15.5 \%)$ bought the food exclusively for themselves. In the next question, respondents should identify where they buy food most often (they could give more answers). As can be seen from Figure 1, the most common place to buy food was a supermarket $(30.7 \%)$.

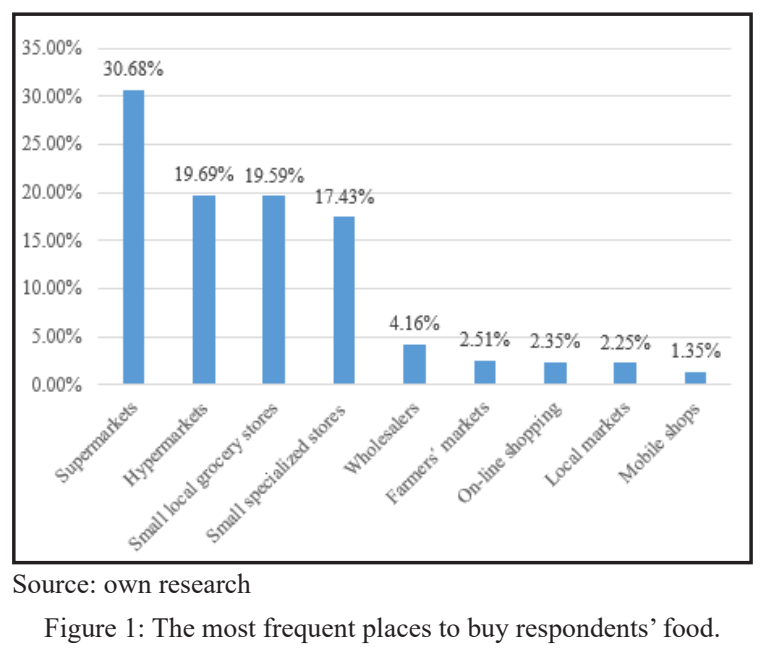

Other favourite stores were hypermarkets and small local grocery stores (both almost 20\%). Small specialized stores $(17.4 \%)$ are also very popular. The research shows different results from the INCOMA survey (Skála, 2017), which conducts regular consumer research called Shopping Monitor. The results from 2017 show that consumers in the Czech Republic do their shopping mostly in hypermarkets (46\%), and only $17 \%$ of them choose supermarkets. In small stores, food is bought by up to $24 \%$ of consumers - the prevalence of hypermarkets in the Czech Republic is more than 10 years old. This difference is mainly because there is only one city in the Vysočina Region with 50,000 inhabitants (Jihlava) and hypermarket chains place their stores in the vicinity of larger cities. Regional producers (especially SMEs) may find it difficult to place their products in the market, the distribution has been frequently identified to be the challenge (Dreyer et al., 2014; Gellynck et al., 2012). Region Vysočina is one of the few in the Czech Republic that has established a network of shops selling regional products in 2012 (Vysočina Region, 2018), with focus on the production certified with the label Vysočina Regional Product - logos should be displayed in the shops (in May 2018, there have been 35 members of the network). Bošková, Ratinger and Kličková (2016) think it was an attempt in the right direction, but the network fails in exhibiting a certain level of cohesion in marketing regional products.

Respondents also say they mostly buy their food $1-3$ times a week $(391$, i.e. $47.7 \%)$, or $4-6$ times a week (232, i.e. $28.3 \%$ ), as shown in Figure 2.

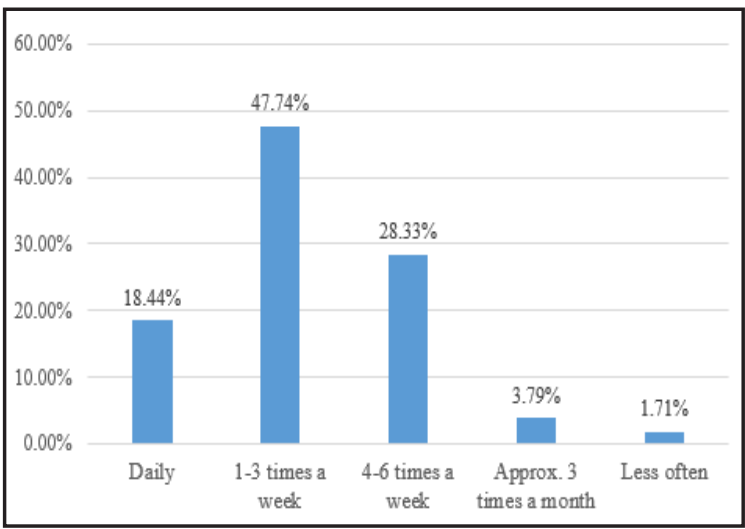

Source: own research

Figure 2: Frequency of respondents' food purchases.

The shopping habits were examined by the question asking whether the respondents were focused on impulse behaviour. Nearly half of them (406) said they mostly went to the shop with a particular idea, but their choice depended on the present or special offer. Almost 13\% (104) of the respondents can do without a shopping plan, while the rest $(38 \% ; 309)$ stick to the previously written list.

Furthermore, respondents were supposed to determine what factors influence their choice of food, and to what extent. From their responses, it is clear their choice mostly follows the brand (1.37) and the price (1.97) (Table 3). Respondents from the Vysočina Region do not differ from other consumers in the Czech Republic, for whom the food price has long been one 


\begin{tabular}{|l|c|c|c|}
\hline \multicolumn{5}{|c|}{$\begin{array}{c}\text { To what extent are your food choices influenced by the following factors? } \\
\text { 1 - significant influence, 5 - no influence (mean - 3) }\end{array}$} \\
\hline Factors & Average & Dispersion & Standard deviation \\
\hline Brand & 1.37 & 1.377 & 1.174 \\
\hline Price & 1.97 & 1.229 & 1.085 \\
\hline Habits - according to previous experience & 2.47 & 1.304 & 1.166 \\
\hline Origin - made in the Czech Republic & 2.67 & 1.657 & 1.287 \\
\hline The priorities of my family / my own priorities & 2.69 & 1.537 & 1.240 \\
\hline Positive information from acquaintances / friends & 2.75 & 1.321 & 1.150 \\
\hline Advertisement & 2.85 & 1.662 & 1.289 \\
\hline Quality confirmed by the labeling on the packaging & 2.91 & 1.599 & 1.265 \\
\hline Nutritional values & 2.93 & 1.556 & 1.247 \\
\hline Environmental friendliness of the product & 3.02 & 1.445 & 1.202 \\
\hline Origin - made abroad & 3.10 & 1.557 & 1.248 \\
\hline Media information & 3.33 & 1.467 & 1.211 \\
\hline
\end{tabular}

Source: own research

Table 3: Factors affecting food purchases.

of the essential factors in their choice (Hes, 2008). On the other hand, Pícha and Skořepa (2018) claim, that those respondents who prefer food with a regional label, do not consider the price as strongly important.

The origin of food plays an important part, the Czech food origin (2.67) was slightly more significant for the respondents than the foreign production (3.1). The results are in line with the research of Kalábová, Mokrý and Turčínková (2013) - their data showed a higher preference of domestic food compared to those from abroad for consumers in Vysočina Region (unlike other regions of the Czech Republic).

Interestingly, of these factors, respondents have attributed the smallest influence on their food purchases that of media (3.33). Also, the quality confirmed by the labelling on the packaging also has only an average impact on them, f.e. the research of Šánová et al. (2017) and Horská et al. (2011) indicated that qualitative parameters are generally very important for the Czech customers when buying food. Our results may indicate that respondents do not see the labels on the food packaging as a strong signal of quality.

In the following part, the hypotheses on the dependence of the gender and age of the respondents were tested, using the Pearson chi-quadrate test. To evaluate the results of the research, the correspondence analysis was used, too, as another suitable method of evaluating the categorical type of data, which makes it possible to compare the results from the contingency table (Zámková, Prokop, 2014).
Test of Hypothesis H1: Preference of the food from the Vysočina Region depends on the respondents' gender.

Statistical analysis of the question whether respondents prefer food from the Vysočina Region showed a significant dependence on the respondents' gender $\left(\chi^{2}=24.01 ; p=0.00002\right)$.

The origin of the food is not important for men, they also tend more not to take into account the fact that the food is from Vysočina Region (see Table 4). The results are not surprising, as many types of researches in the Czech Republic (f.e. Turčínková, Brychtová and Urbánek, 2012; Stávková et al., 2007) demonstrated that behaviour of men and women shows considerable differences when shopping for food.

\section{Test of Hypothesis H2: Preference of the food from the Vysočina Region depends on the respondents' age.}

Statistical analysis of the question whether respondents prefer food from the Vysočina Region showed dependence on the respondents' age $\left(\chi^{2}=2.616 ; p=0.03202\right)$, but the differences between age groups are not significant (see Table 5). Origin of the food is not for the respondents under the age of 25 . On the other hand, respondents with age over 65 years highly prefer food from the Vysočina Region.

Figure 3 displays how respondents of different age categories prefer regional food, nearby points in the graphical output of CA analysis mean that respondents of age over 65 try to buy food 


\begin{tabular}{|c|c|c|c|c|}
\hline \multicolumn{5}{|c|}{ Respondents' gender (column rel. frequencies) } \\
\hline \multicolumn{2}{|r|}{$\begin{array}{l}\text { When you buy food, do you prefer products from the Vysočina } \\
\text { Region? }\end{array}$} & Female & \multicolumn{2}{|c|}{ Male } \\
\hline $\mathbf{A}$ & I disregard the origin of the food when buying it & $12.26 \%$ & \multicolumn{2}{|c|}{$18.64 \%$} \\
\hline B & $\begin{array}{l}\text { I only sometimes take into account the fact that the product } \\
\text { comes from the Region Vysočina }\end{array}$ & $48.82 \%$ & \multicolumn{2}{|c|}{$58.28 \%$} \\
\hline $\mathbf{C}$ & Preferentially, I try to buy food from the Vysočina Region & $31.18 \%$ & \multicolumn{2}{|c|}{$18.93 \%$} \\
\hline D & I clearly prefer food from the Vysočina Region & $7.74 \%$ & \multicolumn{2}{|c|}{$4.14 \%$} \\
\hline \multicolumn{2}{|c|}{ Total relative frequency } & $100 \%$ & \multicolumn{2}{|c|}{$100 \%$} \\
\hline \multicolumn{2}{|c|}{ Pearson's chi-squared test } & $\chi^{2}$ & sv & $\mathbf{P}$ \\
\hline \multicolumn{2}{|c|}{ Pearson's chi-squared } & 24.00963 & $\mathrm{df}=3$ & $\mathrm{p}=0.00002$ \\
\hline
\end{tabular}

Source: own research

Table 4: Preference of the food from the Vysočina Region in dependence on the respondents' gender.

\begin{tabular}{|c|c|c|c|c|c|c|c|}
\hline \multicolumn{8}{|c|}{ Respondents' gender (column rel. frequencies) } \\
\hline \multicolumn{2}{|c|}{$\begin{array}{l}\text { When you buy food, do you prefer } \\
\text { products from the Vysočina Region? }\end{array}$} & $\begin{array}{l}\text { Up to } 25 \\
\text { years old }\end{array}$ & $\begin{array}{l}26-35 \\
\text { y.o. }\end{array}$ & $\begin{array}{c}36-45 \\
\text { y.o. }\end{array}$ & $\begin{array}{l}46 .-55 \\
\text { y.o. }\end{array}$ & $\begin{array}{l}56-65 \\
\text { y.0. }\end{array}$ & $\begin{array}{c}\text { Over } 65 \\
\text { years old }\end{array}$ \\
\hline $\mathbf{A}$ & $\begin{array}{l}\text { I disregard the origin } \\
\text { of the food when buying it }\end{array}$ & $20.42 \%$ & $16.44 \%$ & $7.78 \%$ & $13.93 \%$ & $17.36 \%$ & $10.71 \%$ \\
\hline B & $\begin{array}{l}\text { I only sometimes take } \\
\text { into account the fact that } \\
\text { the product comes } \\
\text { from the Region Vysočina }\end{array}$ & $53.93 \%$ & $46.58 \%$ & $55.09 \%$ & $52.46 \%$ & $56.20 \%$ & $51.79 \%$ \\
\hline $\mathbf{C}$ & $\begin{array}{l}\text { Preferentially, I try to buy } \\
\text { food from the Vysočina } \\
\text { Region }\end{array}$ & $21.99 \%$ & $28.77 \%$ & $29.94 \%$ & $27.87 \%$ & $23.14 \%$ & $23.21 \%$ \\
\hline D & $\begin{array}{l}\text { I clearly prefer food } \\
\text { from the Vysočina Region }\end{array}$ & $3.66 \%$ & $8.22 \%$ & $7.19 \%$ & $5.74 \%$ & $3.31 \%$ & $14.29 \%$ \\
\hline \multicolumn{2}{|c|}{ Total relative frequency } & $100 \%$ & $100 \%$ & $100 \%$ & $100 \%$ & $100 \%$ & $100 \%$ \\
\hline \multicolumn{2}{|c|}{ Pearson's chi-squared test } & & \multicolumn{2}{|c|}{$\chi^{2}$} & sv & & $\mathrm{P}$ \\
\hline \multicolumn{2}{|c|}{ Pearson's chi-squared } & & \multicolumn{2}{|c|}{2.61624} & $\mathrm{df}=15$ & & $\mathrm{p}=0.03202$ \\
\hline
\end{tabular}

Source: own research

Table 5: Preference of the food from the Vysočina Region in dependence on the respondent‘s age.

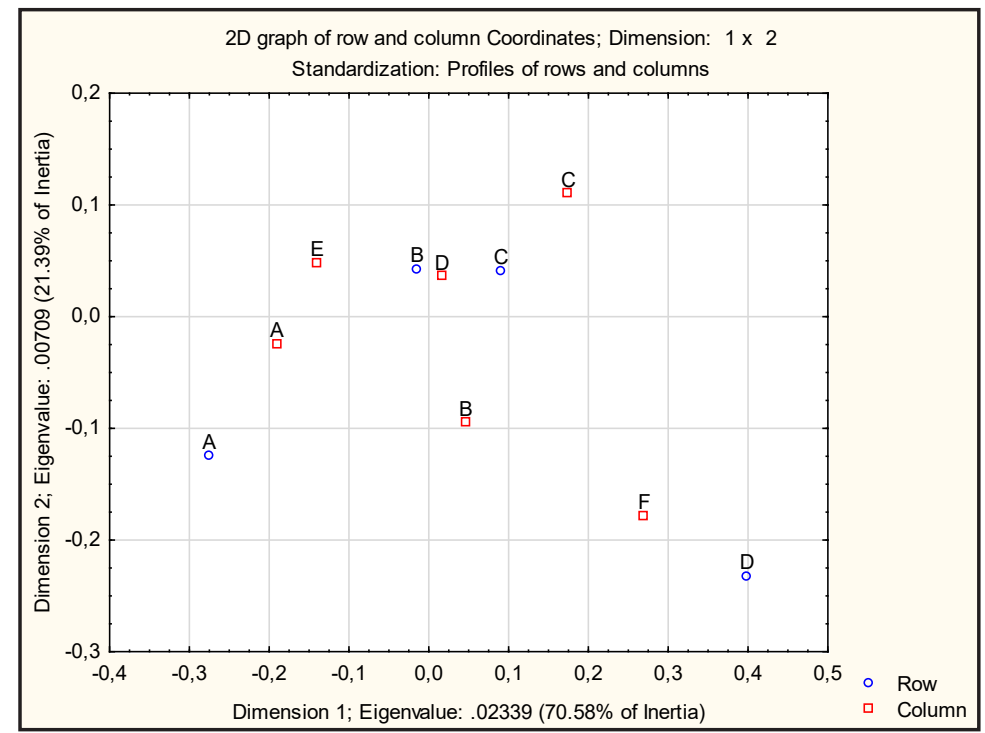

Source: own research

Figure 3: Correspondence Analysis - Preference of the regional food according to the age of respondents in the Vysočina Region. 
from Vysočina with the strongest preference (Category D). On the other hand, it is visible, that respondents that are younger than 25, are the ones that disregard origin of the food (Category A).

\section{Conclusion}

Regional food products represent a cultural richness of regions, but as Minta (2015) highlights, in many cases consumers in the local market undervalue them. Regional food however may play an important role in building local identity (Bingen, 2012). Regional food production is supported in the Czech Republic with the strong marketing communication, however, success of such campaigns is dependent on their ability to reach adequate target market (Pícha, Skořepa, 2018). The similar situation is on the Polish market. F.e. Borowska (in Bryla, 2015) listed weaknesses of market development for traditional and regional products in Poland, such as low recognition of products, insufficient confirmation of the premium quality with certificates, low number of the specialised distribution channels or shortage of financial support for adequate marketing communication. Regional food labelling may be interesting marketing support for small and medium agricultural and food enterprises (f.e. small local farmers) who has a limited budget for their marketing and business investment. This general specific financial situation of those small Czech farmers has confirmed by the research of Řezbová et al. (2013). Our research focused on Vysočina Region in the Czech Republic and the presented findings revealed that respondents from Vysočina Region claim that when buying food, the brand and price play the most significant role. Other factors, such as their habits and the origin of the products (the fact that they were made in the Czech Republic) are also important. Inhabitants of Vysočina seem to prefer local production, the similar results showed the research of Kalábová et al. (2013). The data regarding preference of the regional food showed interesting results. Regional food is strongly preferred by women and older consumers (especially those of age over 65), as it was proved by statistical test based on contingency table. Jarossová and Pazurikova (2014) also stated that women in Slovakia tend to know regional labels and prefer buying regional food significantly more than men. Younger respondents (younger than 25) tend not to pay attention to the origin of the food. It is often observed that young consumers have specific ideas about the quality of the product and its image, they are more confident (Benda Prokeinová, Paluchová, 2014). Aprile, Caputo and Nayga (2015) observed a similar situation on the Italian market. From the marketing perspective, it is important to understand who buys regional food and why is valuable for targeting efforts by producers, retailers, shop owners, restaurants, and others needing information on consumer demand for regional food. Previous analysis (Chalupová, Rojík, Prokop, 2016) confirmed that the preference of regional food in Vysočina Region is strongly depends on the residence in Vysočina Region districts, the lowest preference of the Vysočina regional food is in Žd'ár nad Sázavou district, respondents living in this district being significantly different in their preferences from the others. The authors are aware of the limitations of the research, as it would be important to know opinions of the Vysočina Region visitors, as the regional labels also aim at them, test awareness and attitudes towards this labelled production on other regional markets to identify possible business potential. The research should also focus on the experience of the firms - those that take part in the regional certification systems and the ones that stay willingly away from the regional labelling systems.

\section{Acknowledgements}

This research article was supported by IGS VŠPJ 2018 - Regionální značení jako konkurenční výhoda and IGA PEF CZU (CULS) 2019B0006 - Atributy řízení alternativních business modelů v produkci potravin.

\section{Corresponding authors}

Ing. Martina Chalupová, Ph.D.

Department of Economics, College of Polytechnics Jihlava, Tolstého 16, 58601 Jihlava, Czech Republic Phone: +420 567 1412013, E-mail: martina.chalupova@vspj.cz

\section{References}

[1] Aprile, M. C., Caputo V. and Nayga Jr., R. M. (2016) "Consumers' Preferences and Attitudes Toward Local Food Products“, Journal of Food Products Marketing, Vol. 22, No. 1, pp. 19-42. E-ISSN 1540-4102, ISSN 1045-4446. DOI 10.1080/10454446.2014.949990.

[2] Benda Prokeinová, R. and Paluchová, J. (2014) "Identification of the Patterns Behavior Consumptions by Using Chosen Tools of Data Mining - Association Rules“, AGRIS On-Line Papers in Economics and Informatics, Vol. 6, No. 3, pp. 3-12. ISSN 1804-193. 
[3] Bingen, J. (2012) "Labels of Origin for Food, the New Economy and Opportunities for Rural Development in the US", Agriculture and Human Values, Vol. 29, No. 4, pp. 543-552. E-ISSN 1572-8366. DOI 10.1007/s10460-012-9400-z.

[4] Bošková, I., Ratinger, T. and Kličková, K. (2016) “The food industry structure under the effect of increasing number of regional products and small processing entities in the Czech Republic", $149^{\text {th }}$ EAAE Seminar 'Structural change in agri-food chains: new relations between farm sector, food industry and retail sector' Rennes, France. [Online]. Available: file://C:/Users/chalupm/AppData/ Local/Temp/Boskova\%20et\%20al_149EAAE_Rennes.pdf. [Accesed 3 Jun 2018].

[5] Blake, M. K., Mellor, J. and Crane, J. (2010) "Buying Local Food: Shopping Practices, and Consumption Networks in Defining Food as 'Local'", Annals of the Association of Ameican Geographer, Vol. 100, No. 2. E-ISSN 2469-4460, ISSN 2469-4452. DOI 10.1080/00045601003595545.

[6] Born, B. and Purcell, M. (2006) "Avoiding the Local Trap: Scale and Food Systems in Planning Research", Journal of Planning Education and Research, Vol. 26, pp. 195-207. E-ISSN 15526577 , ISSN 0739 456X. DOI 10.1177/0739456X06291389.

[7] Bryla, P. (2015) "The role of appeals to tradition in origin food marketing. A survey among Polish consumers", Appetite, Vol. 91, pp. 302-310. ISSN 0195-6663. DOI 10.1016/j.appet.2015.04.056.

[8] Chalupová, M., Prokop, M. and Rojík, S. (2016) "Preference of the Regional Food and Recognition of Regional Labels in Vysočina Region (Czech Republic)“, European Countryside, Mendel University in Brno, Czech Republic, pp. 109-122. ISSN 1803-8417. DOI 10.1515/euco-2016-0009.

[9] Čadilová, K. (2011) "Regionální značení v České republice a na Slovensku" (Regional Branding Throughout Europe), Collection of papers 'Regionální značení napříč Evropou', $1^{\text {st }}$ ed., Prague: Asociace regionálních značek, o.s.,, 8 p. ISBN 978-80-254-9506-3. (In Czech).

[10] Czech Statistical Office (2015) "Kraj Vysočina", Prague. [Online]. Available: https://www.czso.cz/ csu/czso/zakladni-tendence-demografickeho-socialniho-a-ekonomickeho-vyvoje-kraje-vysocina2013-dsdmcqx1nq. [Accessed: 8. Jan 2019]. (In Czech).

[11] De Bruin, R. (2011) "Regional labelling and regional products in the Netherlands“, In Čadilová, K. "Regionální značení v České republice a na Slovensku", $11^{\text {st }}$ ed., Prague: Asociace regionálních značek, o.s., pp. 62-73. ISBN 978-80-254-9506-3. (In Czech).

[12] De Lind, L. B. (2011) "Are Local Food and the Local Food Movement Taking Us Where We Want To Go? Or Are We Hitching Our Wagons to the Wrong Stars?", Agricultural and Human Values, Vol. 28, No. 2, pp 273-283. ISSN 0889-048X. DOI 10.1007/s10460-010-9263-0.

[13] Di Franco, G. (2016) "Multiple correspondence analysis: one only or several techniques?", Quality \& Quantity, Vol. 50, No. 3, pp 1299-1315. E-ISSN 1573-7845, ISSN 0033-5177. DOI 10.1007/s11135-015-0206-0.

[14] Dreyer, H. C., Strandhagen, J. O., Thomassen, M. K., Romsdal, A. and Gran, E. (2014) "Supply Chain Design and Control Principles in Local Food Production: A Norwegian Case Study“, Journal on Food System Dynamics, Vol. 5, No. 2, ISSN 1869-6945. DOI 10.18461/ijfsd.v5i2.521.

[15] Fonte, M. (2010) "Europe's integration in the diversities of local food nad local knowledge“, In: Fonte, M., Papadopoulos, A. G. (eds.) "Naming food after places. Food relocalization and knowledge dynamics in rural development", pp. 265-273. Farnham, Ashgate.

[16] Gellynck, X., Kühne, B., B., Carraresi, L. and Stranieri, S. (2012) "Market orientation and marketing management of traditional food producers in the EU“, British Food Journal, Vol. 114, No. 4, pp 481-499. ISSN 0007-070X. DOI 10.1108/00070701211219513.

[17] Giovannucci, D., Barham, E. and Pirog, R. (2010) "Defining and marketing 'local' foods: geographical indications for US products“, The Journal of World Intellectual Property, Vol. 13, No. 2, pp. 94-120. E-ISSN 1747-1796. DOI 10.1111/j.1747-1796.2009.00370.x.

[18] Fogarassy, C., Nguyen, H. H., Olah, J. and Popp, J. (2018) "Transition management applications to accelerate sustainable food consumption - comparative analysis between Switzerland and Hungary, Journal of International Studies, Vol. 11, No. 3, pp. 31-43. E-ISSN 2306-3483, ISSN 2071-8330. DOI 10.14254/2071-8330.2018/11-3/3. 
[19] Hájková, H. (2014) "Možnosti využití regionální značky 'Vysočina - regionální produkt v cestovním ruchu'“(Possibilities of use of regional mark - Vysočina - regional product in tourism), In Jedlička, P. "Hradecké ekonomické dny 2014, Ekonomický rozvoj a management regionů", Hradec Králové: Gaudeamus, pp. 270 -280, ISBN 978-80-7435-366-6.

[20] Hebák, P., Hustopecký, J. and Malá, I. (2010) "Vícerozměrné statistické metody“ (Multidimensional statistical methods), Prague: Informatorium, spol. s.r.o. ISBN 978-80-7333-036-1. (In Czech).

[21] Hendl, J. (2012) "Přehled statistických metod: analýza a metaanalýza dat" (Review of statistical methods: analysis and metaanalýsis of data), $4^{\text {th }}$ ed. Prague: Portál. (In Czech). 736 p. ISBN 978-80-262-0200-4.

[22] Healy, N., McDonagh, J. (2009) "Commodification and Conflict: What Can the Irish Approach to Protected Area Management Tell Us?“, Society \& Natural Resources, Vol. 22, No. 4, pp, 381-391. E-ISSN 1521-0723, ISSN 0894-1920. DOI 10.1080/08941920801978622.

[23] Hes, A. (2008) "Chování spotřebitele při nákupu potravin“ (Behaviour of consumer in food purchasing), $1^{\text {st }}$ ed. Prague: Alfa nakladatelství. ISBN 978-80-903962-0-3. (In Czech).

[24] Horská, E., Ürgeová, J., Prokeinová, R. (2011) "Consumers' food choice and quality perception: Comparative analysis of selected Central European countries“, Agricultural Economics - Czech, Vol. 57, No. 10, pp. 493-499. E-ISSN 1805-9295, ISSN 0139-570X. DOI 10.17221/103/2011-AGRICECON.

[25] Ittersum Van, K., Meulenberg, M. T. G., Trijp, H. C. M. and Candel, M. J. J. M (2007) "Consumers“ Appreciation of Regional Certification Labels: A Pan-European Study“, Journal of Agricultural Economics, Vol. 58, No. 1, pp. 1-23. E-ISSN 1477-9552. DOI 10.1111/j.1477-9552.2007.00080.x.

[26] Ilbery, B. and Maye, D. (2007) "Marketing sustainable food production in Europe: case study evidence from two Dutch labelling schemes“, Tijdschrift voor Economische en Sociale Geografie, Vol. 98, pp. 507-518. E-ISSN 1467-9663. DOI 10.1111/j.1467-9663.2007.00418.x.

[27] Jarossová, M. A. and Pazuriková, V. (2014) "Traditional and regional food: the knowledge of regional labelling،, In Studia commercialia Bratislavensia: Scientific Journal of Faculty of Commerce, University of Economics in Bratislava, Faculty of Business, Vol. 7, No. 28, pp. 520-536. ISSN 1337-7493. (in Slovak).

[28] Kalábová, J., Mokrý, S. and Turčínková, J. (2013) "Regional differences of consumer preferences when shopping for regional products", Acta Universitatis Agriculturae et Silviculturae Mendelianae Brunensis, Vol. 56, No. 7, pp. 2255-2259. E-ISSN 2464-8310, ISSN 1211-8516. DOI 10.11118/actaun201361072255.

[29] Lošták, M., Karanikolas, P., Draganová, M. and Zagata, L. (2014) "Local quality and certification schemes as new forms of governance in sustainability transition, in Sutherland“, In L.-A., Darnhofer, I., Wilson, G. A., Zagata, L. (eds.) "Transition Pathways towards Sustainability in Agriculture, Case studies from Europe". CABI, 246 p. ISBN 1780642199.

[30] Loureiro, M. L. and Umberger, W. J. (2005) "Assessing Consumer Preferences for Country -of-Origin Labelling“", Journal of Agricultural and Applied Economics, Vol. 37, No. 1, pp. 49-63. ISSN 1074-0708. DOI 10.1017/S1074070800007094.

[31] Maitah, M., Hodrab, R., Malec, K. and Shaneb, S. A. (2015) "Exploring the Determinants of Consumer Behavior in West Bank, Towards Domestic and Imported Dairy Products", Acta Universitatis Agriculturae et Silviculturae Mendelianae Brunensis. Vol. 63, No. 1, pp. 355-368. E-ISSN 2464-8310, ISSN 1211-8516. DOI 10.11118/actaun201563010355.

[32] McEntee, J. (2010) "Contemporary and Traditional Localism: Conceptualisation of Rural Local Food“, Local Environment: The International Journal of Justice and Sustainability, Vol. 15, No. 9, pp. 785-803. ISSN 1469-6711. DOI 10.1080/13549839.2010.509390.

[33] Minta, S. (2015) "Regional food products: only for tourists or also for residents", Agriculture \& Forestry, Vol. 61, No. 1, pp. 51-58. E-ISSN 1800-6492, ISSN 0554-5579. DOI 10.17707/AgricultForest.61.1.06.

[34] Musová, Z., Musa, H. and Ludhova, L. (2018) "Environmentally responsible purchasing in Slovakia", Economics and Sociology", Vol. 11, No. 4, pp. 289-305. E- ISSN 2306-3459, ISSN 2071-789X. DOI 10.14254/2071-789X.2018/11-4/19. 
[35] Pícha, K. and Skořepa, L. (2018) "Preference to food with a regional brand“, Quality - Access to Success. Vol. 19, No. 162, pp. 134-139. ISSN 1582-2559.

[36] Reiff, M, Surmanová, K., Balcerzak, A. P. and Pietrzak, M. B. (2016) "Multiple Criteria Analysis of European Union Agriculture", Journal of International Studies, Vol. 9, No 3, pp. 62-74. E-ISSN 2306-3483, ISSN 2071-8330. DOI 10.14254/2071-8330.2016/9-3/5.

[37] Řezbová, H., Rosochatecká, E. and Žídková, E. (2013) "Impact of investments in agriculture on the structure of long-term assete", INPROFORUM, The International Scientific Conference. University of South Bohemia in České Budějovice. ISSN 2336-6788. (In Czech).

[38] Schermer, M. (2015) "From 'Food from Nowhere' to 'Food from Here': changing producerconsumer relations in Austria“, Agricultural Human Values. Vol 32. pp. 121-132. E-ISSN 1572-8366, ISSN 0889-048X. DOI 10.1007/s10460-014-9529-z.

[39] Skála, Z. (2017) "Papírové letáky čte 61 procent domácnosti“" (61 per cents of households read paper leaflets), In [Online]. Available: https://www.gfk.com/.../2017/171213_GfK_TZ_GfK_Shopping Monitor_2018_czfin.p. [Accessed: 23 Jan. 2019]. (In Czech).

[40] Stávková, J., Prudilová, H. and Toufarová, Z. and Nagyoová, L. (2007) "Factors influencing the consumer behaviour when buying food“, Agricultural Economics, Vol. 53, pp. 276-284. ISSN 0139-570X. DOI 10.17221/983-AGRICECON.

[41] Sonnino, R. and Marsden, T. (2005) "Beyond the divide: rethinking relationships between alternative and conventional food networks in Europe“, Journal of Economic Geography, pp 181-199. E-ISSN 1468-2710, ISSN 1468-2702. DOI 10.1093/jeg/lbi006.

[42] Šánová, P., Svobodová, J. and Laputková, A. (2018) "Using Multiple Correspondence Analysis to Evaluate Selected Aspects of Behaviour of Consumers Purchasing Local Food Products", Acta Universitatis Agriculturae et Silviculturae Mendelianae Brunensis. Vol. 65, No. 6, pp. 2083-2093. E-ISSN 2464-8310, ISSN 1211-8516. DOI 10.11118/actaun201765062083.

[43] Van Der Ploeg, J. (2008) "The New Peasantries: Struggles For Autonomy and Sustainability in an Era of Empire and Globalization“, London, Sterling, Earthscan. ISBN 978-1-84407-558-4. DOI 10.1111/j.1471-0366.2011.00323.x.

[44] Turčínková, J. and Kalábová, J. (2011) "Preference regionálních potravinářských produktů v České republice a na Slovensku" (Regional Food Products Preference in the Czech and Slovak Republics), In Petranová, D., Čábyová, L. "Špecifiká regionálneho a neziskového marketingu". Trnava, Slovakia: Faculty of Massmedial Communication, University of St. Cyril and Metod in Trnava, pp. 206-209. ISBN 978-80-8105-333-7. (In Czech).

[45] Turčínková, J., Brychtová, J. and Urbánek, J. (2012) "Preferences of men and women in the Czech Republic when shopping for food", Acta Universitatis Agriculturae et Silviculturae Mendelianae Brunensis, Vol 60, No. 7, pp 425-432. E-ISSN 2464-8310, ISSN 1211-8516. DOI 10.11118/actaun201260070425.

[46] Valenta, O. and Hladík, P. (2011) "Budoucnost kvality a bezpečnosti potravin v Česku" (Future of quality and safety of food in Czech Republic), Prague: Sociologické nakladatelství pro Technologické centrum AV ČR, 1st ed. ISBN 978-80-7419-056-8. (In Czech).

[47] Vysočina Region (2018) "Gastronomy. Regional Products". [Online]. Available: http://www.regionvysocina.cz/temata/temata/gastronomie/regionalni-produkty. [Accesed: 3. Jan 2019]. (In Czech).

[48] Wilson, G. A. and Whitehead, I. (2012) "Local Rural Product as a Relic Spatial Strategy in Globalised Rural Spaces: Evidence from County Clare (Ireland)“, Journal of Rural Studies, Vol. 28, pp.199-207, ISSN 0743-0167. DOI 10.1016/j.jrurstud.2012.01.003.

[49] Zámková, M. and Prokop, M. (2014) "Comparison of consumer behavior of Slovaks and Czechs in the market of organic products by using correspondence analysis", Acta Universitatis Agriculturae et Silviculturae Mendelianae Brunensis. Vol 62, No. 4, pp. 783-795. E-ISSN 2464-8310, ISSN 1211-8516. DOI 10.11118/actaun201462040783. 